https://doi.org/10.11646/phytotaxa.332.1.4

\title{
Rediscovery of a halophytic endemic and rare species of Portulaca (Portulacaceae) from central Argentina: morphology and its phylogenetic position
}

\author{
JUAN JOSE CANTERO ${ }^{1,2 *}$, GLORIA E. BARBOZA ${ }^{2,3} \&$ GILBERTO OCAMPO ${ }^{4}$ \\ IDepartamento Biología Agrícola, Facultad de Agronomía y Veterinaria, Universidad Nacional de Rio Cuarto (UNRC), Ruta Nac. 36, \\ Km.601,5804 Río Cuarto, Córdoba, Argentina; email: juanjocantero@gmail.com \\ ${ }^{2}$ Instituto Multidisciplinario de Biología Vegetal (IMBIV-CONICET)-Universidad Nacional de Córdoba (UNC), Av. Vélez Sársfield 299, \\ CC 495, X5000HVA, Córdoba, Argentina. \\ ${ }^{3}$ Facultad de Ciencias Químicas, UNC. Haya de la Torre y M. Allende s.n., Córdoba, Argentina. \\ ${ }^{4}$ Departamento de Biología, Centro de Ciencias Básica, Universidad Autónoma de Aguascalientes, Avenida Universidad 940, Ciudad \\ Universitaria, C.P. 20131, Aguascalientes, México. \\ *Author for correspondence
}

\begin{abstract}
Portulaca ragonesei (Portulacaceae), an extreme halophyte species from Salina de Ambargasta (central Argentina), is here illustrated and re-described based on morphological evidence. In addition, molecular data shows that this endemic species is one of the earliest-divergent lineages of the Oleracea clade. This is a critically endangered species that can be morphologically distinguished by its sprouting geophyte habit, the linear leaves, and the presence of a constriction at the apex of the pixidium where only one seed is found.
\end{abstract}

Keywords: halophyte, phylogeny, Portulaca ragonesei, Salina de Ambargasta

\section{Introduction}

Portulaca Linnaeus (1753: 445) is the only genus belonging to Portulacaceae Juss. a monotypic family according to the molecular studies by Nyffeler \& Eggli (2010), and Ocampo \& Columbus (2012). The genus has a worldwide distribution, and it mainly occur in the tropics and subtropics, and comprises over than 100 species (see e.g., Ocampo \& Columbus 2012, Kokubugata et al. 2015).

The flora of Argentina includes 23 species of Portulaca (see Legrand 1948; www.floraargentina.edu.ar) being 11 endemics. The native species grow along a latitudinal gradient from northern to central ranges (Jujuy to Buenos Aires Provinces) with the cosmopolitan P. oleracea Linnaeus (1753: 445) reaching the southernmost point at Río Negro Province (Suárez de Cullen 1984).

Portulaca ragonesei Legrand (1949: 333) was described to accommodate an undefined population found in 1947 by the Argentine botanist Arturo Ragonese during his preparation of a phytosociological study of the halophilous vegetation of central Argentina (published later in 1951). Ragonese collected this species in an area he called "Salinas Grandes" (Fig. 1A, Córdoba, Argentina), but he did not include detailed locality information in the type specimen and the protologue. At mid latitudes of central Argentina, the Salinas Grandes $\left(4700 \mathrm{~km}^{2}\right)$, together with Salina de Ambargasta $\left(4200 \mathrm{~km}^{2}\right)$, the San Bernardo $\left(7.2 \mathrm{~km}^{2}\right)$, and La Antigua $\left(410 \mathrm{~km}^{2}\right)$, assemble one of the largest saline complexes in the world (Zanor et al. 2012). Natural salt pans or salt flats ("salina" in Spanish) are flat expanses of ground covered with salt and other minerals, usually shining white under the sun. All these salinas are located in the broken foreland basin of Sierras Pampeanas (Jordan \& Allmendinger 1986), occupying a large tectonic depression, namely Cuenca Saliniana (Álvarez et al. 1990) (Fig. 1 B).

Portulaca ragonesei remained as an enigmatic species (sensu Eggli \& Ford-Werntz 2004) and was not considered in more contemporaneous taxonomic, anatomical, or phylogenetic studies (Ocampo 2013, 2015, Ocampo \& Columbus 2012, Ocampo et al. 2013). In addition, Legrand's description was based only on the type specimen and some flower characters were not described due to a lack of proper material.

Therefore, we decided to revisit the locus classicus of $P$. ragonesei to search for possible new populations of 
this halophytic and rare endemic species. On the basis of the Ragonese's information (Ragonese 1951), and after several field trips without locating $P$. ragonesei during the last decade at Salinas Grandes, the entire Cuenca Saliniana complex was explored. Finally, in 2015, we found populations of P. ragonesei not in Salinas Grandes but in Salina de Ambargasta.

The aim of this work is to re-describe $P$. ragonesei using the recently collected specimens. In addition, molecular data was acquired to seek the phylogenetic position of this endemic species.

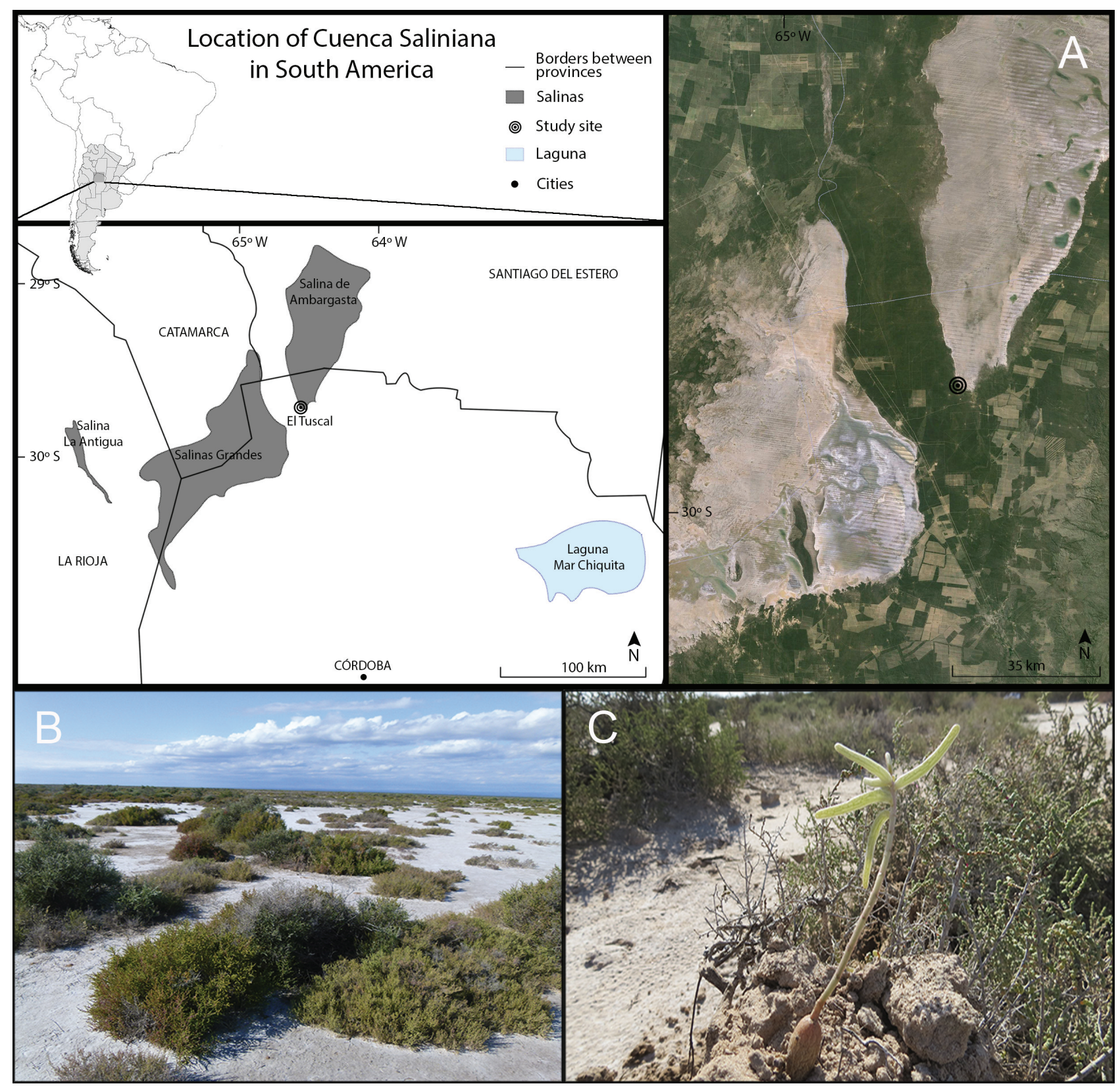

FIGURE 1. Distribution map of Portulaca ragonesei. A. Cuenca Saliniana (Córdoba, Argentina). B. Halophytic bushland in Salina of Ambargasta. C. Habit of $P$. ragonesei.

\section{Material and Methods}

\section{Study area}

Salina de Ambargasta $\left(28^{\circ} 42^{\prime} / 29^{\circ} 45^{\prime} \mathrm{S}\right.$; $63^{\circ} 57^{\prime} / 64^{\circ} 38^{\prime} \mathrm{W}$; Fig. 1B) geologically is considered a playa. Playa settings are dynamic landforms presenting an active and interrelated set of sedimentary environments mainly controlled by the hydrological balance (Hardie et al. 1978, Handford 1981, Rosen 1994). Regional rainfall in Salina de Ambargasta ranges from 500 to $600 \mathrm{~mm} / \mathrm{yr}$ and the total annual evapotranspiration can reach $1300 \mathrm{~mm} / \mathrm{yr}$. 
Collection site of Portulaca ragonesei corresponds to the closed system area of W-Ambargasta, which is dominated by evaporation and considered as part of the "dry mudflat sedimentary subenvironments" by Zanor et al. (2012). Sediments in the dry mudflat are composed mostly of poorly sorted, reddish-brown fine silts primarily composed of quartz, K-feldspar, andesine, augite, biotite and halite (Zanor et al. 2012). Sediments are capped by an efflorescent salt crust (up to $0.5 \mathrm{~cm}$ thick) composed of halite. Vegetation of the dry mudflats is characterized by dominance of many Chenopodiaceae Vent. s.str. halophytic species like Allenrolfea vaginata (Grisebach 1874: 85) Kuntze (1891: 546), Heterostachys ritteriana (Moquin-Tandon 1840: 109) Ungern-Sternberg (1876: 332), Suaeda divaricata MoquinTandon (1840: 123), Atriplex undulata (Moquin-Tandon 1849: 110.) D. Dietrich (1852: 536), Atriplex lampa (MoquinTandon 1849: 110) D. Dietrich (1852: 536), and others such as Lycium infaustum Miers (1854: 192) and Cyclolepis genistoides Gillies ex D. Don (1832: 392). The physiognomy of the community integrated by all these halophytic species is a bushland with three strata $(I=0-10 \mathrm{~cm} ; \mathrm{II}=10-40 ; \mathrm{III}=40-120)$, and $20-40 \%$ cover (Fig. $1 \mathrm{C}$ ).

\section{Morphological observations}

Field observations were carried out in Salina de Ambargasta during summer and fall 2015-2017. Morphological variation was measured on 10 individuals using a ruler and a micrometer. Photos of the habitat and habit were taken in situ by the authors of the present paper. The specimens were deposited in herbarium CORD (acronym according to Thiers 2017+). Seeds were directly coated in gold without a critical-point drying procedure and analyzed using scanning electron microscopy. Samples were observed with a JEOL JSM-840 microscope (Jeol Inc., Peabody, Massachusetts, USA). The resulting image was edited in Adobe Photoshop CS4 version 11.0.2 (Adobe Systems Inc., San Jose, California, USA) for background subtraction and image level adjustments.

\section{Molecular datasets and phylogenetic analyses}

Leaves of Portulaca ragonesei were dried in silica gel and genomic DNA was extracted using the modified CTAB protocol of Doyle \& Doyle (1987). The nuclear ribosomal marker ITS (ITS1, the 5.8S gene, and ITS2) was amplified using primers designed by Cheng et al. (2016) for angiosperms and following the PCR protocol used in Ocampo \& Columbus (2012). The PCR product was sent to Macrogen Korea for purification and sequencing.

It has been shown that a combined data matrix of ITS, the $n d h F, p s b D$-trnT spacer, and the $n d h A$ intron data provides a well-supported backbone phylogeny, enough to show the placement of species with only ITS sequences (e.g., Ocampo et al. 2013). Therefore, DNA data of those markers from representative taxa of Portulacaceae was downloaded from GenBank to obtain a combined data matrix. Sequences were aligned using MUSCLE v. 3.7 (Edgar 2004) followed by manual correction in MEGA 7 (Kumar et al. 2016). A Bayesian analysis was performed in MrBayes version 3.2.6 (Ronquist \& Huelsenbeck 2003), using the best-fit model of evolution for each individual marker provided by MrModeltest version 2.3 (Nylander 2004) under the Akaike Information Criterion (Akaike 1974). Bayesian analysis was run with two duplicates for 10,000,000 generations, saving trees each 1,000 generations. An allcompat consensus tree was obtained ignoring the first $25 \%$ of trees to include only those found after stationarity was reached.

\section{Results}

Phylogenetic analysis

DNA sequences used to obtain the combined data matrix are shown in Appendix 1. The model of evolution selected for ITS and $n d h F$ was GTR $+\mathrm{I}+\mathrm{G}$, and the model for the $p s b D$-trnTspacer and the $n d h A$ intron was GTR $+\mathrm{G}$. The resulting phylogenetic tree (Fig. 4) shows that Portulaca ragonesei was found as one of the early-divergent lineages of the Oleracea clade, although its relationships with other species of the group are not well supported.

\section{Taxonomic treatment}

Portulaca ragonesei D. Legrand (1949: 333, tab. 2).

Type:-ARGENTINA. “Córdoba: El Tuscal, Salinas Grandes, 28 April 1948, Ragonese s.n. (A. 69511) (holotype MVM!, isotype CORD00002591!) (Figs. 2, and 3). 

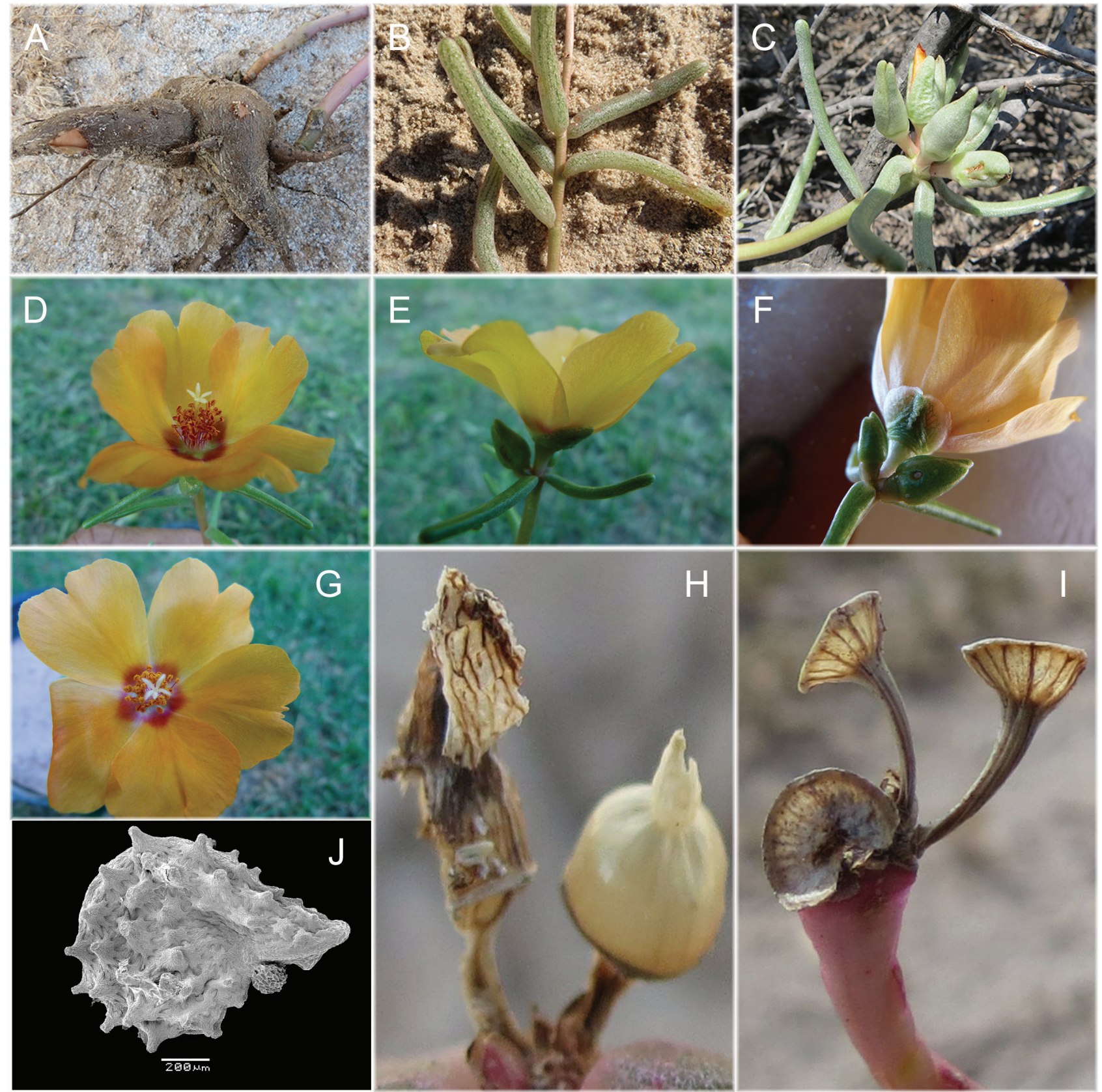

FIGURE 2. Morphology of Portulaca ragonesei. A. Taproot; B. Leaves; C. Buds; D. Flower, lateral view; E. Flower showing calyx; F. Flower, longitudinal section; G. Flower, upper view; H. Fruit; I. Post-dehiscent fruits. J. Seed .

Improved description:-Herbs perennial, succulent, glabrous, ca. $40 \mathrm{~cm}$ long. Taproot thick, light to dark brown, 6-12 cm long, from which other roots sprout laterally. Stems reddish purple to pink, prostate to ascending, simple or few branched, up to $50 \mathrm{~cm}$ long $\times 0.2-0.5 \mathrm{~cm}$ diam. Leaves usually alternate, subopposite at the apex, linear, terete, fleshy, shiny, white greenish, sometimes red-tinged, $(0.7-) 1.5-4.8(-5.5) \times 0.2-0.5 \mathrm{~cm}$, base prolonged as a spurlike ca. $2 \mathrm{~mm}$, apex rounded, glabrous, subssesile, petiole $0.2-0.3 \mathrm{~mm}$; axillary hairs absent. Inflorescence a sessile terminal head, (1-)2-4(-7)-flowered, subtended by a whorl of 3-5 leaves. Buds red-lead, ca. $18 \mathrm{~mm}$, subtended by small fleshy ovate-acuminate whitish bracts with green a midrib, ca. $3.6 \mathrm{~mm}$; flowers $3.5-4 \mathrm{~cm}$ diam, short-pedicellate, pedicels 5-7 mm; sepals 2, fleshy, subequal, keeled, greenish, 0.8-1.1 $\times 0.5-0.8 \mathrm{~cm}$, the larger one widely ovate, retuse at apex, with a hyaline margin $2-3 \mathrm{~mm}$ wide, the shorter one ovate-lanceolate, shortly apiculate, and with a scarcely hyaline margin; petals 5 , quincuncial, dark yellow to orange-yellowish with a reddish spot in the adaxial surface at the base, triangular-ovate to ovate, emarginate, notch $0.3-0.5 \mathrm{~cm}$ deep, base unguiculate, $2.3-2.8 \times 2.3-2.5$ $\mathrm{cm}$; stamens 50 , filaments $5-8 \mathrm{~mm}$, white at the base becoming reddish purple towards the apex, glabrous; anthers ca. $1 \mathrm{~mm}$ long, reddish purple, thecae parallel; gynoecium 18-21 mm long, ovary ovoid, $2 \mathrm{~mm}$ long, many-ovulated, 
style exerted beyond the stamens, white, 13-15 mm long, stigma white, 5-lobed (rarely 4-lobed), the lobes oblonglanceolate 2-4 mm long, the stigmatic surfaces with long hairs, ca. $0.3 \mathrm{~mm}$. Capsule (pixidium) circumscissile, light brown, base conspicuously dark, brown nerved, ca. 4.5-5.0 $\mathrm{mm}$ alt., multiseminate, long pedicellate, dehiscence line close to the base, operculum fusiform with vestigial corolla with age, and with a constriction at its apex forming a cell where one seed is placed, pericarp thin; fruiting pedicel curved upward, costate, 3-4(-5) mm. Seeds dark brown, shiny, subreniform, ca. $1.5 \mathrm{~mm}$ in diameter, individual cells elongated, anticlinal walls undulate with U-type pattern, periclinal walls par-convex, par-conical.

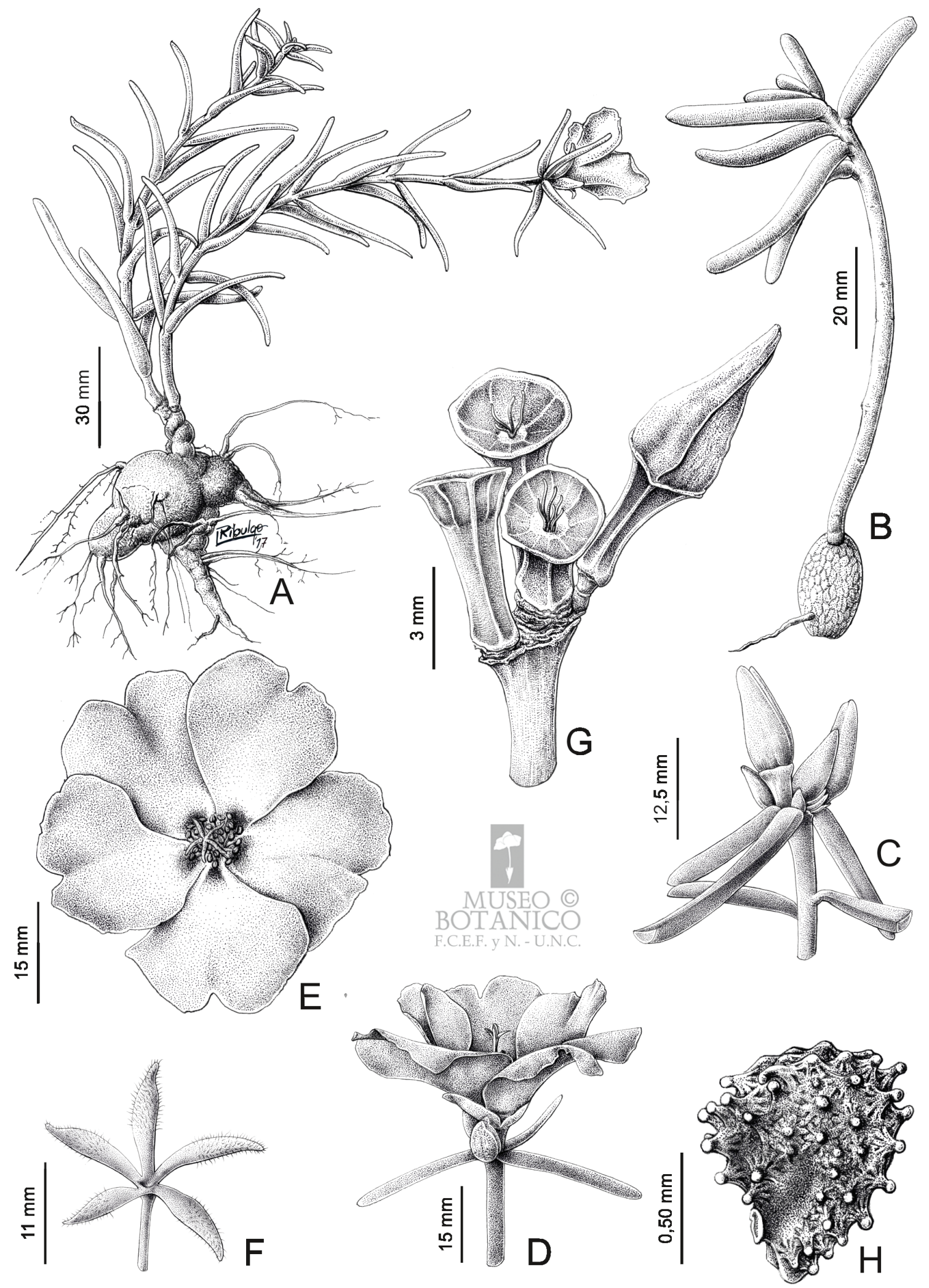

FIGURE 3. Portulaca ragonesei. A. Habit; B. Young sprout; C. Flower buds; D. Flower, lateral view; E. Flower, upper view; F. Stigma; G. Pixidia (one fruit complete and the others without the operculum); H. Seed. Drawn by L. Ribulgo. 


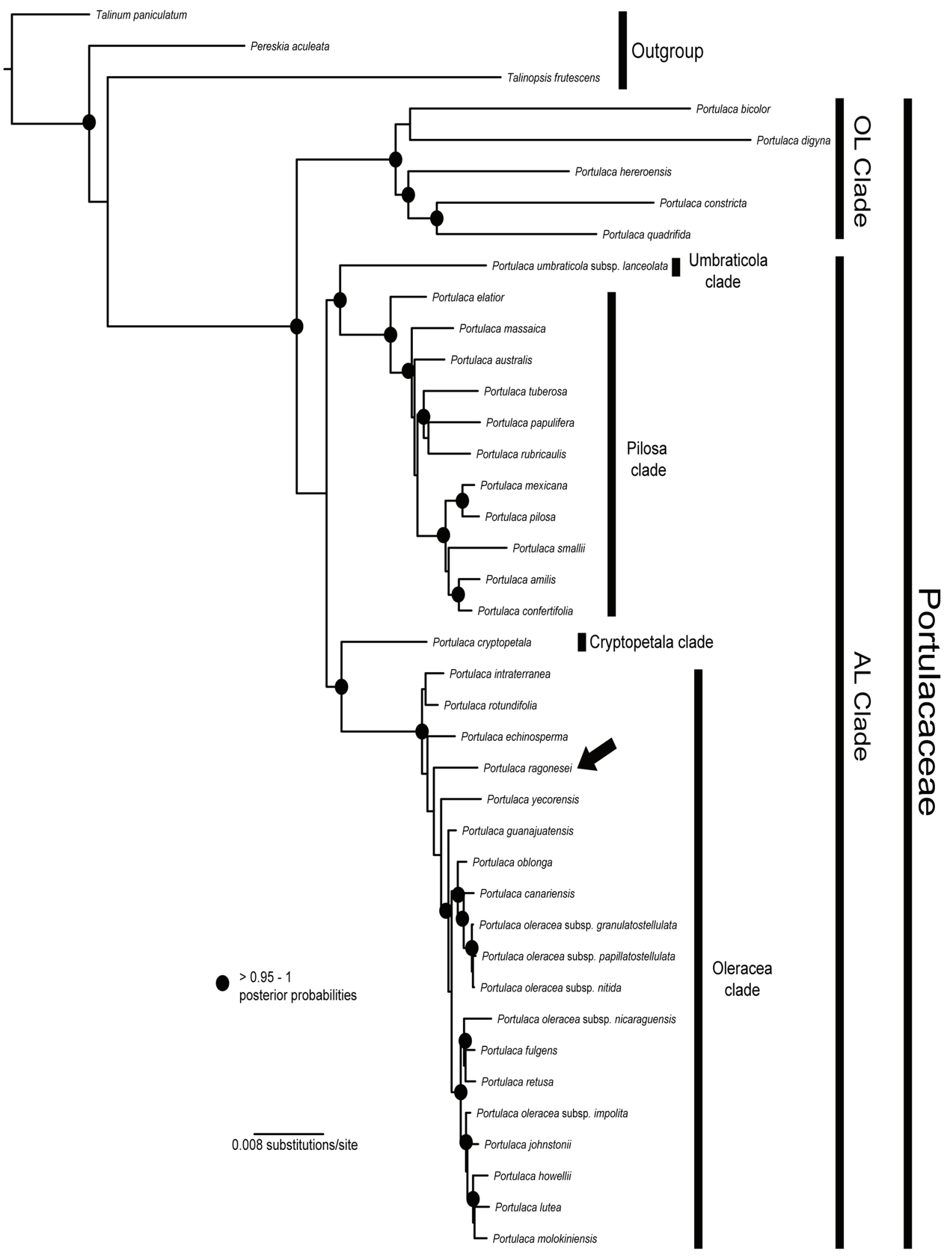

FIGURE 4. Evolutionary relationships of Portulaca ragonesei. Bayesian allcompat tree from analysis of a combined data matrix of ITS, $n d h F, p s b D$-trnT spacer, and $n d h A$ intron sequences. A black arrow shows the position of $P$. ragonesei in the phylogeny. 
Distribution and habitat:-Portulaca ragonesei is an extreme halophyte endemic from central Argentina, inhabiting the southern side of Salinas of Ambargasta (Province of Córdoba, Department of Tulumba, Fig. 1), at ca. $140 \mathrm{~m}$ a.s.l. It is found in saline dry mudflats, where is locally abundant in the Allenrolfea + Salicornia + Heterostachys bushland community that remains without a formal syntaxonomic level (Martínez Carretero et al. 2016). Typically, it spreads over the basal stratum of the community as prostrate-ascendent succulent herb among basal branches of bushes (Fig. 1B); in this patchy environment, P. ragonesei inhabits small sediment micro-domes where is less affected by floodings.

Phenology:- Portulaca ragonesei is a geophyte sprouting from a tap root system every year at beginning of spring, after the first rains. The species flowers in December. Flowers open at sunset for not more than four hours. Fruits are found from January to May. Aerial parts die with first frozen days at fall, but the tap root system is persistent throughout the life of the plant.

Notes on the holotype:-When the Uruguayan Diego Legrand described this species, he designed the holotype (A. 69511) referring it to Laboratorio de Botánica, Ministerio de Agricultura de Buenos Aires (today BAB herbarium). Probably, he asked on loan specimens from different herbaria and he had at hand the specimen A. 69511 from BAB. After that, this specimen never came back to Argentina and so, it remains currently housed at MVM.

Conservation status:-Portulaca ragonesei is currently known only from one site, and the observed population has less than 250 individuals. Therefore, it should be considered as a very small or restricted population and we propose to assess it as Critically Endangered (IUCN 2014). The area of occupancy is calculated to be less than $10 \mathrm{~km}^{2}$ (Criterion B2a) and the species was again collected in the surroundings of the original site of the holotype after 67 years.

Additional specimens examined:-ARGENTINA. Córdoba, Tulumba, La Costa, ca. $4 \mathrm{~km}$ del desvío

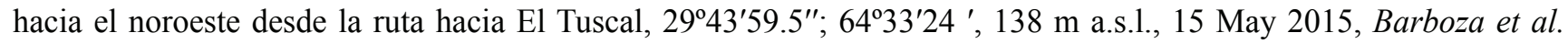
4400 (CORD00086497!); Salinas de Ambargasta, en la propia salina y los alrededores de la Costa, 29 43'50.3"S, 64³3'32,7'W, 140 m a.s.1., 7 December 2016, Barboza et al. 4601 (CORD00056275).

\section{Discussion}

The phylogenetic analysis retrieved a tree that is consistent with the results of Ocampo \& Columbus (2012), where Portulacaceae and its major subclades are strongly supported (posterior probability $=1$ ). The evolutionary relationships of Portulaca ragonesei are not clear, but it was found to be member of the Oleracea clade, within the AL clade, which members can be placed in subsect. Portulaca in Geesink's classification (1969). Taxa of the Oleracea clade are mainly characterized by the presence of inconspicuous leaf axillary hairs (Ocampo \& Columbus 2012). It is noteworthy that $P$. ragonesei is found as one of the earliest-divergent lineages of the Oleracea clade, along with other species that are endemic to Australia [P. intraterranea J.M.Black (1926: 283)], North America [P. yecorensis Henrickson \& T. Van Devender (1999: 1002)], and South America [P. echinosperma Hauman (1925: 441), P. rotundifolia R.E. Fries (1905: 149)]. Legrand (1962) proposed that $P$. echinosperma and P. ragonesei, both Argentinian endemics, were close-related species based on large seed size $(>1.5 \mathrm{~mm})$, linear leaves, a usually truncate leaf apex, and the presence of few leaves subtending the capitula. Although the phylogenetic relationships of $P$. ragonesei in this study are not conclusive, Legrand's hypothesis cannot be discarded.

\section{Acknowledgements}

We are grateful to L. Ribulgo (Córdoba) for the excellent illustration, to P. Brandolin (Río Cuarto) for technical assistance in preparing color figures, and to A. Adabache (Aguascalientes for obtaining the SEM picture. This research was supported by grants from the Secretaría de Ciencia y Tecnología de la Universidad Nacional de Córdoba and Secretaría de Ciencia y Tecnología de la Universidad Nacional de Río Cuarto. Gilberto Ocampo acknowledges support by the Programa para el Desarrollo Profesional Docente (PRODEP, Secretaría de Educación Pública, Mexico) under fund \#UAA-PTC-169 and by the Universidad Autónoma de Aguascalientes (Aguascalientes, Mexico) under fund \#PIB16-3. 


\section{References}

Akaike, H. (1974) A new look at the statistical model identification. IEEE Transactions on Automatic Control 19: 716-723. https://doi.org/10.1109/TAC.1974.1100705

Álvarez, L.A., Fernandez Seveso, F., Pérez, M.A. \& Bollati, N.D. (1990) Estratigrafía de la Cuenca Saliniana. $11^{\circ}$ Congreso Geológico Argentino, Actas, vol. 2. Asociación Geológica Argentina, ,San Juan, pp. 145-148.

Black, J.M. (1926) Additions to the flora of South Australia. Transactions and Proceedings of the Royal Society of South Australia 50: 283-286.

Cheng, T., Xu, C., Lei, L., Li, C., Zhang, Y. \& Zhou, S. (2016) Barcoding the kingdom Plantae: new PCR primers for ITS regions of plants with improved universality and specificity. Molecular Ecology Resources 16: 138-149.

Dietrich, D.N.F. (1852) Synopsis Plantarum, vol. 5. B.F. Voigtii, Vimariae, 587 pp.

Don, D. (1832) Descriptive catalogue of the Compositae contained in the herbarium of Dr. Gillies; with some additions from others sources. Philosophical Magazine, or Annals of Chemistry, Mathematics, Astronomy, Natural, History and General Science 11: 387-392.

Doyle, J.J. \& Doyle, J.L. (1987) A rapid DNA isolation procedure for small quantities of fresh leaf tissue. Phytochemical Bulletin 19: $11-15$.

Edgar, R.C. (2004) MUSCLE: multiple sequence alignment with high accuracy and high throughput. Nucleic Acids Research 32: 17921797.

https://doi.org/10.1093/nar/gkh340

Eggli, U. \& Ford-Werntz, D. (2004) Portulacaceae. In: Eggli, U. (Ed.) Illustrated Handbook of Succulent Plants: Dicotyledons. Springer, Verlag, pp. 370-425.

Flora Argentina (2012+) Flora Argentina. Plantas Vasculares de la República Argentina. Available from: http://www.floraargentina.edu.ar (accessed 13 November 2017)

Fries, R.E. (1905) Zur Kenntnis der Alpinen Flora im Nördlichen Argentinien. Nova Acta Regiae Societatis Scientiarum Upsaliensis, ser. 41 (1): 1-205.

Geesink, R. (1969) An account of the genus Portulaca in Indo-Australia and the Pacific. Blumea 17: 275-301.

Grisebach, A. (1874) Plantae Lorentzianae. Abhandlungen der Königlichen Gesellschaft der Wissenschaften zu Göttingen 19: 49-278.

Handford, C.R. (1981) A process-sedimentary framework for characterizing recent and ancient sabkhas. Sedimentary Geology 30 (4): 255-265. https://doi.org/10.1016/0037-0738(81)90023-3

Hardie, L.A., Smoot, J.P. \& Eugster, H.P. (1978) Saline lakes and their deposits: a sedimentological approach. In: Matter, A. \& Tucker, M.E. (Eds.) Modern and Ancient Lake Sediments, vol, 2. Blackwell Publishing Ltd., Oxford, UK, pp. 7-41. https://doi.org/10.1002/9781444303698.ch2

Hauman, L.L. (1925) Notes Floristiques (Dicotylédones de L’Argentine). Anales del Museo Nacional de Buenos Aires 32: $395-474$.

Henrickson, J. \& Van Devender, T.R. (1999) A new species of Portulaca (Portulacaceae). Sida 18 (4): 1001-1007.

Jordan, T.E. \& Allmendinger, R.W. (1986) The Sierras Pampeanas of Argentina: A modern analogue of Rocky Mountain foreland deformation. American Journal of Science 286: 737-764.

https://doi.org/10.2475/ajs.286.10.737

Kokubugata, G., Kato, H., Iamonico, D., Umemoto, H., Ito, T., Nakamura, K., Murakami, N. \& Yokota, M. (2015) Taxonomic reexamination of Portulaca boninensis (Portulacaceae) in the Bonin (Ogasawara) Islands of Japan using molecular and morphological data. Phytotaxa 217 (3): 279-287.

https://doi.org/10.11646/phytotaxa.217.3.5

Kumar, S., Stecher, G. \& Tamura, K. (2016) MEGA7: Molecular Evolutionary Genetics Analysis version 7.0 for bigger datasets. Molecular Biology and Evolution 33: 1870-1874.

https://doi.org/10.1093/molbev/msw054

Kuntze, O. (1891) Revisio Generum Plantarum, vol. 2. A. Félix, Leipzig, 634 pp.

Legrand, C.D. (1949) Las especies del género Portulaca en la Argentina. Lilloa 17: 311-376.

Legrand, C.D. (1962) Las especies americanas de Portulaca. Anales del Museo Nacional de Historia Natural de Montevideo 7: 1-147.

Linnaeus, C. (1753) Species Plantarum, vol. 1. Laurentii Salvii, Holmia, 560 pp.

Martínez Carretero, E., Faggi, A.M., Fontana, J.L., Aceñolaza, P., Gandullo, R., Cabido, M., Iriart, D., Prado, D., Roig, F.A. \& Eskuche, U. (2016) Prodromus sinsistemático de la República Argentina y una breve introducción a los estudios fitosociológicos. Boletín de la Sociedad Argentina de Botánica 51 (3): 469-549.

Miers, J. (1854) On the genus Lycium. Annals and Magazine of Natural History 14: 182-194. 
https://doi.org/10.1080/037454809496549

Moquin-Tandon, Ch. H. (1840) Chenopodearum Monographica Enumeratio. P.-J. Loss, Paris, 182 pp.

https://doi.org/10.5962/bhl.title.15484

Moquin-Tandon, Ch. H. (1849) Salsolaceae. In Candolle A.P. de (Ed.) Prodromus Systematis Naturalis Regni Vegetabilis, vol. 13(2). V. Masson., Paris, pp. 40-230.

Nyffeler, R. \& Eggli, U. (2010) Disintegrating Portulacaceae: a new familial classification of the suborder Portulacineae (Caryophyllales) based on molecular and morphological data. Taxon 59: 227-240.

Nylander, J.A.A. (2004) MrModeltest, version 2 (computer program). Available from: https://github.com/nylander/MrModeltest2 (accessed 7 July 2017)

Ocampo, G. (2013) Morphological characterization of seeds in Portulacaceae. Phytotaxa 141 (1): 1-24. https://doi.org/10.11646/phytotaxa.141.1.1

Ocampo, G. (2015) Systematic implications of seed morphological diversity in Portulacaceae (Caryophyllales). Plant Systematic and Evolution 301 (4): 1215-1226. https://doi.org/10.1007/s00606-014-1146-1

Ocampo, G. \& Columbus, J.T. (2010) Molecular phylogenetics of suborder Cactineae (Caryophyllales), including insights into photosynthetic diversification and historical biogeography. American Journal of Botany. 97: 1827-1847. https://doi.org/10.3732/ajb.1000227

Ocampo, G. \& Columbus, J.T. (2012) Molecular phylogenetics, historical biogeography, and chromosome number evolution in Portulaca (Portulacaceae). Molecular Phylogenetics and Evolution 63: 97-112. https://doi.org/10.1016/j.ympev.2011.12.017

Ocampo, G., Koteyeva, N.K. Voznesenskaya, E., Edwards, G.E., Sage, T., Sage, R.F. \& Travis Columbus, J. (2013) Evolution of leaf anatomy and photosynthetic pathways in Portulacaceae. American Journal of Botany 100 (12): 1-15. https://doi.org/10.3732/ajb.1300094

Ragonese, A.E. (1951) La vegetación de la República Argentina. II. Estudio fitosociológico de las Salinas Grandes. Revista Investigaciones Agrícolas 5 (1-2): 1-233.

Ronquist, F. \& Huelsenbeck, J.P. (2003) MrBayes 3: Bayesian phylogenetic inference under mixed models. Bioinformatics 19: 15721574 .

https://doi.org/10.1093/bioinformatics/btg180

Rosen, M.R. (1994) The importance of groundwater in playas: A review of playa classifications and the sedimentology and hydrology of playas. In: Rosen, M.R. (Ed.) Paleoclimate and Basin Evolution of Playa Systems, vol. 289. Geological Society of Amer, U.S.A., pp. $1-18$.

https://doi.org/10.1130/SPE289-p1

Suárez de Cullen, D.A. (1984) Portulacaceae. In: Correa, M. (Dir.) Flora Patagonica, vol. 8 (4 a). Colección Científica I.N.T.A., Buenos Aires, pp. 168-195.

Thiers, B. (2017+) Index Herbariorum: A global directory of public herbaria and associated staff. New York Botanical Garden's Virtual Herbarium. Available from: http://sweetgum.nybg.org/science/ih/ (accesed 13 November 2017)

Ungern-Sternberg, F. (1876) Salicornearum Synopsis. Atti Congresso Internazionale Botanica in Firenze 1874: $259-543$.

Zanor, G., Piovano, E.L., Ariztegui, D. \& Vallet-Coulomb, Ch. (2012) A modern subtropical playa complex: Salina de Ambargasta, central Argentina. Journal of South American Earth Sciences 35: 10-26.

https://doi.org/10.1016/j.jsames.2011.10.007 
APPENDIX 1. GenBank accession numbers used in this study (ITS, $n d h F, \operatorname{trn} T-p s b D$ spacer, $n d h A$ intron). NA, not available.

Portulaca amilis Speg.: JF508527, JF508674, JF508757, HQ241593. Portulaca australis Endl.: JF508531, JF508678, JF508761, JF508612. Portulaca bicolor F. Muell.: JF508532, JF508679, JF508762, HQ241594. Portulaca canariensis Danin \& Reyes-Bet.: JF508535, JF508682, JF508765, JF508614. Portulaca confertifolia Hauman: JF508536, JF508683, JF508766, JF508615. Portulaca constricta M.G. Gilbert: JF508537, JF508684, JF508767, JF508616. Portulaca cryptopetala Speg.: JF508538, JF508685, JF508768, HQ241596. Portulaca digyna F. Muell.: JF508540, JF508687, JF508770, JF508618. Portulaca echinosperma Hauman: JF508541, JF508688, JF508771, HQ241597. Portulaca elatior Mart. ex Rohrb.: JF508542, JF508689, JF508772, HQ241598. Portulaca fulgens Griseb.: JF508547, JF508694, JF508777, JF508623. Portulaca guanajuatensis G. Ocampo: JF508551, JF508698, JF508781, HQ241599. Portulaca hereroensis Schinz: JF508554, JF508701, JF508784, JF508629. Portulaca howellii (D. Legrand) Eliasson: JF508555, JF508702, JF508785, HQ241601. Portulaca intraterranea J.M. Black: JF508556, JF508703, JF508786, JF508630. Portulaca johnstonii Henrickson: JF508557, JF508704, JF508787, JF508631. Portulaca lutea Sol. ex G. Forster: JF508558, JF508705, JF508788, JF508632. Portulaca massaica S.M. Phillips: JF508559, JF508706, JF508789, HQ241600. Portulaca mexicana P. Wilson: JF508561, JF508708, JF508791, JF508634. Portulaca molokiniensis Hobdy: JF508562, JF508709, JF508792, HQ241602. Portulaca oblonga Peter: JF508564, JF508711, JF508794, JF508636. Portulaca oleracera subsp. papillatostellulata Danin \& H.G. Baker: JF508566, JF508713, JF508796, JF508638. Portulaca oleracera subsp. granulatostellulata (Poelln.) Danin \& H.G. Baker: JF508568, JF508715, JF508798, JF508640. Portulaca oleracera subsp. impolita Danin \& H.G. Baker: JF508570, JF508717, JF508800, JF508642. Portulaca oleracera subsp. nicaraguensis Danin \& H.G. Baker: JF508571, JF508718, JF508801, JF508643. Portulaca oleracera subsp. nitida Danin \& H.G. Baker: JF508572, JF508719, JF508802, JF508644. Portulaca papulifera D. Legrand: JF508580, JF508727, JF508810, JF508652. Portulaca pilosa L.: JF508586, JF508733, JF508816, JF508657. Portulaca quadrifida L.: JF508588, JF508735, JF508818, HQ241604. Portulaca ragonesei D. Legrand: MG543910, NA, NA, NA. Portulaca retusa Engelm.: JF508590, JF508737, JF508820, JF508659. Portulaca rotundifolia R.E. Fr.: JF508591, JF508738, JF508821, JF508660. Portulaca rubricaulis Kunth: JF508592, JF508739, JF508822, JF508661. Portulaca smallii P. Wilson JF508595, JF508742, JF508825, JF508663. Portulaca tuberosa Roxb.: JF508599, JF508746, JF508829, JF508667. Portulaca umbraticola Kunth subsp. lanceolata J.F. Matthews \& Ketron: JF508602, JF508749, JF508832, HQ241605. Portulaca yecorensis Henrickson \& T. Van Devender: JF508606, JF508753, JF508836, JF508672. Outgroups. Pereskia aculeata Mill. (Cactaceae): JF508526, JF508673, JF508756, HQ241587. Talinopsis frutescens A. Gray(Montiaceae): JF508607, JF508754, JF508837, HQ241613. Talinum paniculatum (Jacq.) Gaertn. (Talinaceae): JF508608, JF508755, JF508838, HQ241618. 